\title{
Association of microsomal epoxide hydrolase polymorphisms and lung cancer risk
}

\author{
A Gsur ${ }^{*, 1}$, T Zidek ${ }^{2}$, K Schnattinger', E Feik', G Haidinger ${ }^{2,8}$, P Hollaus ${ }^{3,8}$, A Mohn-Staudner ${ }^{4}$, C Armbruster $^{4}$, \\ S Madersbacher ${ }^{5}$, G Schatzl ${ }^{6}$, K Trieb $^{7}, C_{\text {Vutuc }}{ }^{2,8}$ and M Micksche ${ }^{1,8}$ \\ 'Division of Applied and Experimental Oncology, Institute of Cancer Research, University of Vienna, Austria; ${ }^{2}$ Division of Epidemiology, Institute of Cancer \\ Research, University of Vienna, Austria; ${ }^{3}$ Department of Surgery, Pulmological Center, Baumgartner Hoehe, Vienna, Austria; ${ }^{4}$ Department of Internal \\ Medicine, Pulmological Center, Baumgartner Hoehe, Vienna, Austria; ${ }^{5}$ Department of Urology and Andrology, Ludwig Boltzmann Institute for Urological \\ Oncology, Donauspital, Vienna, Austria; ${ }^{6}$ Department of Urology, University of Vienna, Austria; ${ }^{7}$ Department of Orthopedics, University of Vienna, Austria; \\ ${ }^{8}$ Austrian Cancer Society, Vienna, Austria
}

Microsomal epoxide hydrolase $(\mathrm{mEH})$ plays a dual role in the detoxification and activation of tobacco procarcinogens. Two polymorphisms affecting enzyme activity have been described in the exons 3 and 4 of the $\mathrm{mEH}$ gene, which result in the substitution of amino acids histidine to tyrosine at residue 1 13, and arginine to histidine at residue 139, respectively. We performed a hospitalbased case-control study consisting of 277 newly diagnosed lung cancer patients and 496 control subjects to investigate a possible association between these two polymorphisms and lung cancer risk. The polymorphisms were determined by polymerase chain reaction/restriction fragment length polymorphism and TaqMan assay using DNA from peripheral white blood cells. Logistic regression was performed to calculate odds ratios (ORs), confidence limits $(C L)$ and to control for possible confounders. The exon 3 polymorphism of the $\mathrm{mEH}$ gene was associated with a significantly decreased risk of lung cancer. The adjusted $\mathrm{OR}$, calculated relative to subjects with the Tyr I 3/Tyrl I 3 wild type, for the His I I 3/His I I 3 genotype was 0.38 (95\% CL 0.20-0.75). An analysis according to histological subtypes revealed a statistically significant association for adenocarcinomas; the adjusted OR for the His | | $/$ /His | | 3 genotype was 0.40 (95\% CL 0.17-0.94). In contrast, no relationship between the exon 4 polymorphism and lung cancer risk was found. The adjusted OR, calculated relative to the His I39/His I 39 wild type, was for the Arg I39/Arg I 39 genotype I.83 (0.76-4.44). Our results support the hypothesis that genetically reduced $\mathrm{mEH}$ activity may be protective against lung cancer.

British Journal of Cancer (2003) 89, 702-706. doi:I0.1038/sj.bjc.660II 42 www.bjcancer.com

(c) 2003 Cancer Research UK

Keywords: lung cancer; mEH; polymorphism; molecular epidemiology

It is estimated that smoking is responsible for about $90 \%$ of lung cancer cases. Since not all smokers develop lung cancer, it has been hypothesised that polymorphisms in genes encoding enzymes involved in the metabolisms of tobacco carcinogens such as the microsomal epoxide hydrolase $(\mathrm{mEH})$ may influence an individual's susceptibility to lung cancer.

Microsomal epoxide hydrolase, a phase II metabolic enzyme, catalyses the hydrolysis of arene, alkene and aliphatic epoxides from polycyclic aromatic hydrocarbons and aromatic amines. Although this hydrolysis is generally a detoxification reaction because less reactive and more watersoluble trans-dihydrodiols are produced (Oesch, 1973), in the case of some hydrocarbons such as benzo(a)pyrene, present in tobacco smoke, more highly reactive and mutagenic compounds for example the 7,8-diol-9,10 epoxide are generated in the metabolic process (Sims et al, 1974). Thus, $\mathrm{mEH}$ exhibits a dual role of procarcinogen detoxification and activation (Shou et al, 1996) and may be considered a cancer risk factor as well as a protective factor, depending on the carcinogens.

The gene for human $\mathrm{mEH}$, consisting of nine exons, has been mapped with in situ hybridisation to chromosome 1q42.1 (1p11-

*Correspondence: Dr A Gsur, Division of Applied and Experimental Oncology, Institute of Cancer Research, Borschkegasse 8a, A-1090 Vienna, Austria; E-mail: andrea.gsur@univie.ac.at

Received 27 March 2003; revised 8 May 2003; accepted I 4 May 2003 qter) (Hartsfield et al, 1998). In the coding region of the $\mathrm{mEH}$ gene, two relatively common genetic polymorphisms are characterised within exons 3 and 4 . (Hassett et al, 1994a, b). In exon 3 of the $\mathrm{mEH}$ gene, a $\mathrm{C}$ has been substituted for a $\mathrm{T}$, resulting in a tyrosine replacement by histidine at codon 113 . In vitro expression analyses indicate that this amino-acid change results in a $40-50 \%$ decrease in enzyme activity and thus the allele has been called the 'slow allele'. The second polymorphism occurs in exon 4, a $G$ to A transition, causing a histidine to arginine change at codon 139. This polymorphism has been referred to as the 'fast allele' as this change results in a $25 \%$ increase of enzyme activity (Hassett et al, 1994a).

We conducted a hospital-based case-control study of 277 patients with primary lung cancer and 496 controls without a history of cancer, all of them Austrian Caucasians, to investigate whether the $\mathrm{mEH}$ polymorphisms in exons 3 and 4 are associated with lung cancer risk.

\section{MATERIAL AND METHODS}

\section{Study population}

Lung cancer cases were recruited consecutively since January 1997 from the Pulmological Center, Baumgartner Hoehe, Vienna, Austria's largest hospital for the treatment of pulmonary diseases. 
Cases $(n=277)$ were newly diagnosed, previously untreated and histologically confirmed lung cancer patients.

Histological data were available for 255 cases, of those $27.1 \%$ had squamous cell carcinoma, $51.0 \%$ adenocarcinoma, $4.7 \%$ large-cell carcinoma, $14.5 \%$ small-cell carcinoma, $0.7 \%$ alveolarcylinder-cell carcinoma and $2.0 \%$ mixed histological subtypes. Patients were derived from the Surgical Department (34\%) and the Department of Internal Medicine (66\%). The hospitalbased control group $(n=496)$ was recruited at the same time period from the Departments of Urology (41.0\%), Orthopedics (15.6\%), Gynaecology (11.9\%) and Head and Neck (1.9\%) of the University Hospital of Vienna; the Department of Internal Medicine $(16.8 \%)$ and the Department of Surgery $(0.8 \%)$ of the Pulmological Center; the Department of Urology $(1.5 \%)$ of the 'Kaiser Franz Josef Hospital', an outpatient clinic (8.9\%) and relatives of the students involved in this study (1.5\%). Only individuals without a history of cancer were eligible for participation as controls. The human subjects protocol for this study was reviewed and approved by the institutional review boards of the participating hospitals. Written informed consent was obtained from all the included subjects.

\section{Genotyping analyses}

Heparinised peripheral blood mononuclear cells (PBMCs) were isolated by Ficoll-Paque gradient centrifugation (Amersham Pharmacia Biotech, Arlington Heights, IL, USA). Genomic DNA was extracted from PBMC, using QIAamp Blood Kit (Quiagen $\mathrm{GmbH}$, Germany).

The $\mathrm{mEH}$ polymorphisms in exons 3 and 4 were determined by two separate polymerase chain reaction (PCR)-based methods using primers as described by Harrison et al (1999). Briefly, the amplification reactions were carried out in a $50 \mu \mathrm{l}$ volume consisting of $200 \mathrm{ng}$ genomic DNA, $0.2 \mu \mathrm{M}$ of each primer (VBCGenomics, Vienna, Austria), $0.2 \mathrm{~mm}$ deoxynuclotide triphosphate (Roche, Vienna, Austria), $1.5 \mathrm{~mm} \mathrm{MgCl}_{2}, 5 \mu \mathrm{l} 10 \times$ PCR Buffer II (Applied Biosystems, Norwalk, CT, USA) and 1 U AmpliTaq DNA Polymerase (Applied Biosystems). Polymerase chain reactions were performed with a thermocycler 2400 from Applied Biosystems with the following conditions: $94^{\circ} \mathrm{C}$ for $5 \mathrm{~min}$, followed by 35 cycles of $95^{\circ} \mathrm{C}$ for $30 \mathrm{~s}$, annealing temperature of $55^{\circ} \mathrm{C}$ (exon 3 ) or $62^{\circ} \mathrm{C}$ (exon 4) for $30 \mathrm{~s}$ and $72^{\circ} \mathrm{C}$ for $30 \mathrm{~s}$, with a final extension of $72^{\circ} \mathrm{C}$ for $7 \mathrm{~min}$.

A $10 \mu \mathrm{l}$ aliquot of the appropriate PCR product was digested with $10 \mathrm{U}$ of the restriction enzyme EcoRV (exon 3) and RsaI (exon 4) (New England Biolabs, Hitchin, UK) at $37^{\circ} \mathrm{C}$ for $4 \mathrm{~h}$ and separated on a $3 \%$ ethidium bromide-stained agarose gel.

The allelic discrimination of the $\mathrm{mEH}$ exon 3 polymorphism was reassessed with the ABI PRISM 7000 Sequence Detection Systems (Applied Biosystems), using the fluorogenic 5'nuclease assay with TaqMan Minor Groove Binder (MGB) probes. The wild-type TaqMan MGB probe was FAM labelled (5'-TCAACAGATACCCT-
CAC- $3^{\prime}$ ) and the mutant probe was VIC labelled (5'-TCAACAGACACCCTC- $\left.3^{\prime}\right)$. The final volume for each reaction was $25 \mu$, consisting of $12.5 \mu \mathrm{l}$ TaqMan Universal PCR Master Mix (Applied Biosystems), $0.6 \mu \mathrm{M}$ of each primer (forward primer $5^{\prime}$-CTGGAAGAAGCAGGTGGAGATT- $3^{\prime}$ and reverse primer $5^{\prime}$-TCTGGCTGGCGTTTTGC- $3^{\prime}$ ), $0.2 \mu \mathrm{m}$ of each TaqMan probe and $100 \mathrm{ng}$ genomic DNA. The PCR profile was an initial denaturation step at $95^{\circ} \mathrm{C}$ for $10 \mathrm{~min}$ and 40 cycles with $95^{\circ} \mathrm{C}$ for $15 \mathrm{~s}$ and $60^{\circ} \mathrm{C}$ for $1 \mathrm{~min}$, fluorescent signals were measured at $60^{\circ} \mathrm{C}$.

Genotyping was done blinded to case-control status. For quality control, $20 \%$ of the samples were randomly repeated; no discrepancies were observed.

\section{Statistical analyses}

Univariate statistical analyses included descriptive statistics for age, sex, pack-years, $\mathrm{mEH} 3$ and $\mathrm{mEH} 4$. Multiple logistic regressions were performed to calculate odds ratios (ORs) and confidence limits (CL) and to adjust for confounders. Confounders included were age, sex and pack-years of cigarettes smoked. Smoking habits were coded as neversmokers and quartiles of packyears smoked (see Table 2). Deviation of the genotypes from a Hardy-Weinberg equilibrium was assessed using $\chi^{2}$ statistics. The final multiple logistic regression model was: $\log (P($ cancer $) /(1-P$ $($ cancer $))=b_{0}+$ age + sex + pack-year_quartiles $+\mathrm{mEH} 3+$ mEH4 . To evaluate different histological subtypes, squamous cell carcinomas, adenocarcinomas and small-cell carcinomas were separately analysed using multiple logistic regression and including the same confounders as above. All $P$-values are two-sided; $P$-values $<0.05$ were considered to be statistically significant. Analysis of the data was performed using the computer software SPSS for Windows (version 10.0).

\section{RESULTS}

In Table 1 selected characteristics of the study population, which consisted of 277 lung cancer patients and 496 controls, are presented. There were no statistically significant differences between the cases and controls in age, mean age was 64 years in the cases and 63 years in the controls. The percentage of males was $68.2 \%$ for cases and $67.7 \%$ for controls. The means of pack-years for cigarettes smoked showed differences between cases (52.8) and controls (33.5). Furthermore, ORs for lung cancer with respect to quartiles of pack-years are shown in Table 2; a highly significant dose-response relationship was found.

The gene frequencies for controls were not in Hardy-Weinberg equilibrium for the exon 3 polymorphism $(P<0.0001)$ using the conventional polymerase chain reaction/restriction fragment length polymorphism (PCR/RFLP) genotyping, whereas using a fluorogenic $5^{\prime}$ nuclease TaqMan assay they were found to be in Hardy-Weinberg equilibrium $(P=0.93)$. The deviation from Hardy-Weinberg equilibrium was attributable to genotyping

Table I Principal patient characteristics in the study population $(n=773)$

\begin{tabular}{llcc}
\hline Study population & Gender & $\begin{array}{c}\text { Pack-years } \\
\text { Mean (s.d.) }\end{array}$ & $\begin{array}{c}\text { Age (years) } \\
\text { Mean (s.d.) }\end{array}$ \\
\hline Cases $(n=277)$ & Female $(n=88)$ & $44.5(23.1)$ & $64(12)$ \\
& Male $(n=189)$ & $55.7(28.6)$ & $64(11)$ \\
& Total $(n=277)$ & $52.8(27.6)$ & $64(11)$ \\
Controls $(n=496)$ & Female $(n=160)$ & $22.1(16.4)$ & $62(13)$ \\
& Male $(n=336)$ & $36.6(28.5)$ & $63(12)$ \\
All & Total $(n=496)$ & $33.5(27.0)$ & $63(12)$ \\
\hline
\end{tabular}


Table 2 Distribution of quartiles of pack-years of smoked cigarettes in cases and controls and adjusted $\mathrm{ORs}^{\mathrm{a}}$

\begin{tabular}{lcccc}
\hline Pack-years (quartiles) & Cases $(\mathbf{n}=\mathbf{2 7 7})$ & Controls $(\mathbf{n}=\mathbf{4 9 6})$ & OR $(\mathbf{9 5} \% \mathbf{C L})$ & $\boldsymbol{P}$ \\
\hline 0 & $31(11.2 \%)$ & $202(40.7 \%)$ & 1 & \\
$0.1-22.0$ & $26(9.4 \%)$ & $113(22.8 \%)$ & $1.97(1.08-3.57)$ & 0.03 \\
$22.0-38.5$ & $51(18.4 \%)$ & $83(16.7 \%)$ & $5.52(3.18-9.57)$ & 0.00 \\
$38.5-57.7$ & $84(30.3 \%)$ & $48(9.7 \%)$ & $17.91(10.01-32.03)$ & 0.00 \\
$57.7-288.0$ & $85(30.7 \%)$ & $50(10.1 \%)$ & $18.07(10.10-32.34)$ & 0.00 \\
\hline
\end{tabular}

${ }^{a}$ Adjusted for age, gender, $\mathrm{mEH} 4$ and $\mathrm{mEH} 3$.

Table 3 Distribution of the $\mathrm{mEH} 3$ polymorphism in cases and controls and adjusted $\mathrm{OR}^{\mathrm{a}}$

\begin{tabular}{|c|c|c|c|c|c|}
\hline Genotype & Total $(n=773)$ & Cases $(n=277)$ & Controls $(n=496)$ & OR $(95 \% C L)^{a}$ & $P$ \\
\hline $\begin{array}{l}\text { Wild type } \\
\text { Tyrl |3/Tyrl 13 }\end{array}$ & 371 & I 47 (53.0\%) & $224(45.2 \%)$ & I & \\
\hline $\begin{array}{l}\text { Heterozygous } \\
\text { Tyr | |3/His I I }\end{array}$ & 332 & II (4I.2\%) & $218(43.9 \%)$ & $0.77(0.54-1.09)$ & 0.77 \\
\hline $\begin{array}{l}\text { Homozygous } \\
\text { His | |3/His | I3 }\end{array}$ & 70 & $16(5.8 \%)$ & $54(10.9 \%)$ & $0.38(0.20-0.75)$ & 0.014 \\
\hline
\end{tabular}

${ }^{a}$ Adjusted by age, gender, smoking status (pack-years) and mEH4.

Table 4 Distribution of the mEH4 polymorphism in cases and controls and adjusted $\mathrm{OR}^{\mathrm{a}}$

\begin{tabular}{|c|c|c|c|c|c|}
\hline Genotype & Total $(n=773)$ & Cases $(n=277)$ & Controls $(n=496)$ & OR $(95 \% C L)^{a}$ & $P$ \\
\hline \multicolumn{6}{|l|}{ Wildtype } \\
\hline His I 39/His I 39 & 552 & I $86(67.1 \%)$ & $336(67.7 \%)$ & I & \\
\hline Heterozygous & & & & & \\
\hline His I 39/Arg I 39 & 224 & $80(28.9 \%)$ & I 44 (29.0\%) & $1.01(0.69-1.47)$ & 0.95 \\
\hline Homozygous & & & & & \\
\hline Arg | 39/Arg 139 & 27 & II (4.0\%) & $16(3.2 \%)$ & $1.83(0.76-4.44)$ & 0.18 \\
\hline
\end{tabular}

${ }^{a}$ Adjusted for age, gender, smoking status (pack-years) and $\mathrm{mEH} 3$.

Table 5 Distribution of the mEH3 polymorphism in adenocarcinomas and controls and adjusted $\mathrm{ORs}^{\mathrm{a}}$

\begin{tabular}{|c|c|c|c|c|c|}
\hline Genotype & Total $(n=622)$ & Adenocarcinomas $(n=126)$ & Controls $(n=496)$ & OR $(95 \% C L)^{a}$ & $P$ \\
\hline $\begin{array}{l}\text { Wildtype } \\
\text { Tyrl 13/Tyrl } 13\end{array}$ & 296 & $72(57.1 \%)$ & $224(45.2 \%)$ & । & \\
\hline $\begin{array}{l}\text { Heterozygous } \\
\text { Tyrl | 3/His | I3 }\end{array}$ & 264 & $46(36.5 \%)$ & $218(43.9 \%)$ & $0.63(0.40-1.00)$ & 0.048 \\
\hline $\begin{array}{l}\text { Homozygous } \\
\text { His | |3/His I I }\end{array}$ & 62 & $8(6.4 \%)$ & $54(10.9 \%)$ & $0.40(0.17-0.94)$ & 0.035 \\
\hline
\end{tabular}

${ }^{a}$ Adjusted for age, gender, smoking status (pack-years) and $\mathrm{mEH} 4$.

error, as we found $42(57.53 \%)$ of the heterozygote controls and $19(54.29 \%)$ of the heterozygote patients falsely classified as His113 homozygotes (data not shown). For the statistical analysis, only results performed by the TaqMan assay were used for the exon 3 polymorphism (Table 3 ). There was a statistically significant difference in the distribution of genotypes between cases and controls for the exon 3 polymorphism of $\mathrm{mEH}$. The prevalence of the His113/His113 genotype was significantly lower $(P=0.014)$ in the lung cancer cases $(5.8 \%)$ than in the controls (10.9\%). The adjusted OR, calculated relative to subjects with the Tyr113/Tyr113 wild type, was $0.38(95 \%$ CL $0.20-0.75)$. The heterozygous Tyr $113 /$ His 113 genotype was also lower in the cancer group (41.2\%) compared to the control group $(43.9 \%)$, although the difference was not statistically significant $(P=0.77)$.
Table 4 shows the $\mathrm{mEH}$ exon 4 genotype distribution for cases and controls. The gene frequencies for controls were found to be in Hardy-Weinberg equilibrium for the exon 4 polymorphism $(P=0.905)$. The adjusted OR, calculated relative to the His139/ His139 wild type, was 1.01 (95\% CL 0.69-1.47) for the His139/ Arg139 genotype and $1.83(0.76-4.44)$ for the Arg139/Arg139 genotype, respectively.

An analysis according to histological types and the $\mathrm{mEH}$ exon 3 polymorphism was performed, where a statistically significant association for adenocarcinoma was found (Table 5). The adjusted $\mathrm{OR}$, calculated relative to the $\mathrm{mEH}$ exon 3 wild type, for the His $113 /$ His 113 genotype was 0.40 (95\% CL $0.17-0.94)$. Other histological subtypes such as squamous cell carcinoma and smallcell carcinoma revealed no statistically significant association (data not shown). 


\section{DISCUSSION}

In this hospital-based case-control study of Austrian Caucasians, we investigated the association between $\mathrm{mEH}$ genetic polymorphism and the risk of lung cancer. Our results suggest that the variant genotype of the $\mathrm{mEH}$ exon 3 polymorphism is a protective factor for lung cancer, whereas the exon 4 polymorphism of $\mathrm{mEH}$ has no influence on lung cancer risk. Using the conventional PCR/ RFLP genotyping with primers designed by Harrison et al (1999), the alleles for the polymorphism in exon 3 were not in HardyWeinberg equilibrium, whereas the alleles of exon 4 polymorphism were found to be in Hardy - Weinberg equilibrium, arguing against a selection bias. This finding is in accordance with other studies using primers designed by Harrison et al (1999) for the genotyping of the exon 3 polymorphism. In their Caucasian control population, Zhou et al (2001) found genes such as the NADPH quinone oxidoreductase, $\mathrm{N}$-acetyltransferase- 2 and $\mathrm{mEH}$ exon 4 polymorphism in Hardy-Weinberg equilibrium, but not the exon 3 polymorphism. As this finding suggests a misclassification bias, they retested a random of their samples (5\%) using different primers and restriction enzymes. However, they found no discordant results, evidently due to the low percentage of their repeats. They conclude that the deviation from HardyWeinberg equilibrium of the exon 3 polymorphism requires further studies.

The reverse primer of Harrison et al abuts directly at the mutation site and an engineered base change produces an EcoRV restriction enzyme site in the wild type. Within this reverse primer, a $\mathrm{G} \rightarrow \mathrm{A}$ polymorphism at codon 119 is contained (Yoshikawa et al, 2000), which may affect the accuracy of the exon 3 genotyping. Baxter et al (2002) found that this primer mismatch in Tyr113/ His 113 heterozygotes leads to a false His113/His113 genotype when the codon 119 A allele is present. Hence, we reassessed the allelic discrimination of the $\mathrm{mEH}$ exon 3 polymorphism with a fluorogenic 5 'nuclease assay using TaqMan Minor Groove Binder (MGB) probes. Indeed we found $57.53 \%$ of the heterozygote controls and $54.29 \%$ of the heterozygote patients falsely classified as homozygotes. In the statistical analysis, only results performed by the TaqMan assay were included.

The variant alleles His 113 and Arg139 of the mEH polymorphisms were relatively common, allele frequencies in controls were 0.33 and 0.18 , respectively. These frequencies of our control population were comparable to those of previous studies conducted in Caucasian populations, where the frequency of the rare His 113 allele ranged from 0.28 to 0.40 ; of the Arg139 allele from 0.15 to 0.18 (Benhamou et al, 1998; London et al, 2000; ToFigueras et al, 2001).

One of the first studies investigating the association between lung cancer risk and $\mathrm{mEH}$ genotypes was conducted by Benhamou et al (1998), who found a significant dose-response relationship between predicted enzyme activity and lung cancer risk in French Caucasian smokers. Consecutively, a number of case-control studies have examined the influence of the $\mathrm{mEH}$ polymorphisms on lung cancer risk (Persson et al, 1999; Lin et al, 2000; London et al, 2000; To-Figueras et al, 2001; Wu et al, 2001; Zhao et al, 2002; Zhou et al, 2001, 2002), resulting in somewhat inconsistent findings. Recently, Lee et al (2002) performed a meta-analysis of seven published studies and a pooled analysis of four published and four unpublished studies to investigate the association of the $\mathrm{mEH}$ polymorphisms and lung cancer risk. The results of the meta-analysis indicate no statistically significant association between the two $\mathrm{mEH}$ polymorphisms and lung cancer risk. However, in the pooled analysis, comprised of 986 cases and 1633 controls, a significant decrease in lung cancer risk was observed for the exon 3 polymorphic homozygous genotype with an OR of 0.70 ( $95 \%$ confidence interval $(\mathrm{CI})=0.51-0.96)$, adjusted for age, sex, smoking and centre. In contrast, no effect for the exon 4 polymorphism was detectable.

An analysis according to the main histological subtypes, namely adenocarcinoma, squamous cell carcinoma and small-cell carcinoma, revealed a statistically significant association for adenocarcinoma, whereas no significant association was found neither for squamous cell carcinoma nor small-cell carcinoma. This finding is in accordance with the meta-analysis by Lee et al (2002), who found the protective effect of the mEH exon 3 polymorphism stronger for adenocarcinoma than for other histological types.

In conclusion, the results of this Austrian Caucasian study support the hypothesis that genetically reduced $\mathrm{mEH}$ activity may be protective against lung cancer, especially for adenocarcinoma, as we found a statistically significant reduced risk for individuals homozygous for the exon 3 variant allele. Therefore, the genetic polymorphism at exon 3 of the $\mathrm{mEH}$ gene represents a possible mechanism for the modulation of carcinogen disposition that may influence individual susceptibility to cancer development.

\section{ACKNOWLEDGEMENTS}

We thank the chiefs of clinical units who allowed us to study their patients for the purpose of this study (K Ehrenberger, W Höltl, R Kotz, S Leodolter, M Marberger, $\mathrm{N}$ Pridun and $\mathrm{N}$ Vetter) and the physicans and students who are involved in this study (S Aldrian, A Ellend, C Gassner, M Ochsner, K Presich, C Roehrich, T Thuerridl and J Waldmueller). This work was supported by the 'Medizinisch wissenschaftlicher Fonds des Buergermeisters der Stadt Wien', No. 1522.

\section{REFERENCES}

Baxter SW, Choong D-YH, Campbell IG (2002) Microsomal epoxide hydrolase polymorphism and susceptibility to ovarian cancer. Cancer Lett 177: 75-81

Benhamou S, Reinikainen M, Bouchardy C, Dayer P, Hirvonen A (1998) Association between lung cancer and microsomal epoxide hydrolase genotypes. Cancer Res 58: 5291-5293

Harrison DJ, Hubbard AL, MacMillan J, Wyllie AH, Smith CA (1999) Microsomal epoxide hydrolase gene polymorphism and susceptibility to colon cancer. Br J Cancer 79: $168-171$

Hartsfield J-KJ, Sutcliffe MJ, Everett ET, Hassett C, Omiecinski CJ, Saari JA (1998) Assignment 1 of microsomal epoxide hydrolase (EPHX1) to human chromosome 1q42.1 by in situ hybridization. Genet 83: $44-45$

Hassett C, Aicher L, Sidhu JS, Omiecinski CJ (1994a) Human microsomal epoxide hydrolase: genetic polymorphism and functional expression in vitro of amino acid variants. Hum Mol Genet 3: 421-428
Hassett C, Robinson KB, Beck NB, Omiecinski CJ (1994b) The human microsomal epoxide hydrolase gene (EPHX1): complete nucleotide sequence and structural characterization. Genomics 23: $433-442$

Lee WJ, Brennan P, Boffetta P, London SJ, Benhamou S, Rannug A, To F, Ingelman S, Shields P, Gaspari L, Taioli E (2002) Microsomal epoxide hydrolase polymorphisms and lung cancer risk: a quantitative review. Biomarkers 7: $230-241$

Lin P, Wang SL, Wang HJ, Chen KW, Lee HS, Tsai KJ, Chen CY, Lee H (2000) Association of CYP1A1 and microsomal epoxide hydrolase polymorphisms with lung squamous cell carcinoma. $\mathrm{Br} J$ Cancer 82: $852-857$

London SJ, Smart J, Daly AK (2000) Lung cancer risk in relation to genetic polymorphisms of microsomal epoxide hydrolase among AfricanAmericans and Caucasians in Los Angeles County. Lung Cancer 28: $147-155$ 
Oesch F (1973) Mammalian epoxide hydrases: inducible enzymes catalysing the inactivation of carcinogenic and cytotoxic metabolites derived from aromatic and olefinic compounds. Xenobiotica 3: $305-340$

Persson I, Johansson I, Lou YC, Yue QY, Duan LS, Bertilsson L, IngelmanSundberg M (1999) Genetic polymorphism of xenobiotic metabolizing enzymes among Chinese lung cancer patients. Int J Cancer 81: 325 - 329

Shou M, Gonzalez FJ, Gelboin HV (1996) Stereoselective epoxidation and hydration at the K-region of polycyclic aromatic hydrocarbons by cDNAexpressed cytochromes P450 1A1, 1A2, and epoxide hydrolase. Biochemistry 35: $15807-15813$

Sims P, Grover PL, Swaisland A, Pal K, Hewer A (1974) Metabolic activation of benzo(a)pyrene proceeds by a diol-epoxide. Nature 252: 326-328

To-Figueras J, Gene M, Gomez-Catalan J, Pique E, Borrego N, Corbella J (2001) Lung cancer susceptibility in relation to combined polymorphisms of microsomal epoxide hydrolase and glutathione S-transferase P1. Cancer Lett 173: $155-162$

Wu X, Gwyn K, Amos CI, Makan N, Hong WK, Spitz MR (2001) The association of microsomal epoxide hydrolase polymorphisms and lung cancer risk in African-Americans and Mexican-Americans. Carcinogenesis 22: $923-928$

Yoshikawa M, Hiyama K, Ishioka S, Maeda H, Maeda A, Yamakido M (2000) Microsomal epoxide hydrolase genotypes and chronic obstructive pulmonary disease in Japanese. Int J Mol Med 5: 49-53

Zhao H, Spitz MR, Gwyn KM, Wu X (2002) Microsomal epoxide hydrolase polymorphisms and lung cancer risk in non-Hispanic whites. Mol Carcinog 33: 99 - 104

Zhou W, Thurston SW, Liu G, Xu LL, Miller DP, Wain JC, Lynch TJ, Su L, Christiani DC (2001) The interaction between microsomal epoxide hydrolase polymorphisms and cumulative cigarette smoking in different histological subtypes of lung cancer. Cancer Epidemiol Biomarkers Prev 10: $461-466$

Zhou W, Liu G, Thurston SW, Xu LL, Miller DP, Wain JC, Lynch TJ $\mathrm{Su}$ L, Christiani DC (2002) Genetic polymorphisms in $\mathrm{N}$-acetyltransferase-2 and microsomal epoxide hydrolase, cumulative cigarette smoking, and lung cancer. Cancer Epidemiol Biomarkers Prev 11: $15-21$ 